Gambaran Sedimen Urin pada Orang Lanjut Usia yang Mengalami Hipertensi

\title{
Profile of Urine Sediments in Elderly People with Hypertension
}

\section{DINI SARTIKA}

\author{
Rumah Sakit Harapan Magelang \\ Jl. Panembahan Senopati No.11, Jurangombo Utara, Kota Magelang \\ Email : dinie.sartika24@gmail.com
}

\begin{abstract}
Abstrak
Lanjut usia merupakan seseorang yang mencapai usia $>60$ tahun yang rentan mengalami penyakit yang berhubungan dengan proses menua salah satunya hipertensi. Hipertensi merupakan salah satu faktor resiko penyebab terjadinya penyakit gagal ginjal. Seseorang dikatakan hipertensi jika hasil pengukuran tekanan darah sistolik lebih atau sama dengan $140 \mathrm{mmHg}$ dan diastolik lebih atau sama dengan $90 \mathrm{mmHg}$. Tujuan penelitian ini untuk mengetahui bagaimana gambaran sedimen urin pada orang lanjut usia yang mengalami hipertensi. Jenis penelitian ini deskriptif,dengan mengumpulkan data, pengolahan dan penyajian data secara presentase. Jumlah sampel 25 orang dengan kriteria orang lanjut usia yang terkena hipertensi. pemeriksaan urin dilakukan dengan metode Sternheimer-Malbin. Hasil menunjukkan 19 orang (76\%) mengalami hematuria atau kemungkinan adanya infeksi dan 6 orang (24\%) tidak mengalami hematuria. Dari pemeriksaan tersebut juga didapatkan silinder sebanyak 6 orang, yaitu 4 orang $(16 \%)<1 / \mathrm{Lpb}$ dan $>1 / \mathrm{Lpb}$ yaitu 2 orang $(8 \%)$. Silinder ini memberikan gambaran adanya kelainan ginjal. Pemeriksaan sedimen urin pada orang lanjut usia yang mengalami hipertensi dapat memberikan gambaran pada hipertensi renal dengan ditemukannya silinder disertai hematuria mikroskopis.
\end{abstract}

Kata Kunci : Hipertensi ; Gagal Ginjal ; Sedimen Urin

\section{Abstract}

Elderly was a person who reaches the age more than 60 years that susceptible by the aging, such as hypertension. Hypertension was one of the factor for kidney disease. Hypertension is a disease that has systolic blood preasure up to $140 \mathrm{mmHg}$ and diastolic up to $90 \mathrm{mmHg}$. Find out how the description of urine sediment in older people with hypertension. Type of descriptive type, include data collection, processing and presentation of data. Samples were taken as many 25 people with criteria for elderly people affected by hypertension. Urine examination is carried out by the Malbin-Streinheimer painting method. The result showed 19 people (76\%) had hematuria or the possibility of infection and 6 people (24\%) did not have hematuria.from the examination also obtained a cylinder of 6 people, namely 4 people $(16 \%)<1 / \mathrm{Lpb}$ and $>1 / \mathrm{Lpb} 2$ people (8\%). This cylinder provides an overview of kidney abnormalities. Urine sediment examination in elderly people with hypertension gives an overview of renal hypertension with discovery of a cylinder accompanied by microscopic hematuri.

Keywords: Hypertension ; Kidney Failure ; Urine Sediment.

\section{Pendahuluan}

Hipertensi merupakan penyakit yang insidenya (populasi yang beresiko terkena penyakit) yang sangat tinggi di Indonesia. Hipertensi merupakan penyakit degenertaif. Hipertensi 
dikategorikan sebagai the silent disease atau the silent killer karena penderita tidak mengetahui dirinya mengidap hipertensi atau tidak mengetahui sebelum memeriksakan tekanan darahnya. Insiden hipertensi meningkat seiring bertambahnya usian (Bambang, 2011). Hipertensi merupakan manifestasi gangguan keseimbangan hemodinamik sistem kardiovaskuler. Secara umum, orang dikatakan hipertensi apabila tekanan sistole lebih atau sama dengan $140 \mathrm{mmHg}$ dan tekanan diastole lebih atau sama dengan $90 \mathrm{mmHg}$ (Kaplan,2010). Badan Kesehatan Dunia (WHO) menyebutkan jumlah penderita hipertensi akan terus meningkat seiring dengan jumlah penduduk yang bertambah pada 2025 mendatang, diperkirakan sekitar $29 \%$ warga dunia terkena hipertensi. WHO menyebutkan negara ekonomi berkembang memiliki penderita hipertensi sebesar $40 \%$ sedangkan negara maju hanya 35\%. Di Indonesia penderita hipertensi cukup tinggi, yakni mencapai 32\% dari total jumlah penduduk (Widiyani, 2013).

Ginjal merupakan unit penyaring darah sehingga tenaga dorong darah melalui saringan itu menentukan apa yang akan muncul dalam urin, sehingga dengan adanya tekanan darah tinggi memungkinkan protein darah menerobos saringan itu. Dengan demikian jenis silinder dan jumlahnya dalam endapan urin yang berasal dari bentukan protein darah tersebut dapat menggambarkan keadaan ginjal khususnya yang disebabkan oleh kelainan tekanan darah (Syaifudin DAC, 2012).

Orang lanjut usia pada umumnya mengalami penyempitan pembuluh darah. Hal ini menjadi salah satu faktor yang mempengaruhi hipertensi dijumpai pada variasi yang luas sehingga organ ginjal akan mengalami kelainan yang disebabkan karena adanya tekanan darah yang tinggi dengan melewati pembuluh darah yang sempit (Fatmah, 2010).

\section{Metode}

Jenis penelitian ini adalah deskriptif. Populasi dalam penelitian ini adalah seluruh pasien hipertensi yang sedang menjalani rawat inap di Rumah Sakit Harapan Magelang. Sampel atau subjek penelitian ini adalah pasien hipertensi yang memenuhi kriteria pada bulan Januari - Februari 2020 yang dilakukan pemeriksaan sedimen urinnya. Data yang dikumpulkan adalah data sekunder, yaitu data yang diambil melalui catatan rekam medis. Data yang terkumpul diolah untuk dideskripsikan dalam persen.

\section{Hasil dan Pembahasan}

Dari 25 sampel yang diperiksa ditemukan eritrosit dalam sedimen urin $<3 / \mathrm{Lpb}$ sebanyak $24 \%$ dan $>3 / \mathrm{Lpb}$ sebanyak $76 \%$. Adanya eritrosit dalam urin menunjukkan adanya tanda penyakit yang disebut hematuria yang menunjukkan adanya kemungkinan infeksi pada saluran urin atau kandung kemih. Dan hasil pemeriksaan adanya silinder didapatkan sebanyak 6 orang, yaitu $<1 / \mathrm{Lpb}$ sebanyak 4 orang $16 \%$ dan $>1 /$ Lpb sebanyak 2 orang atau $8 \%$. Adanya silinder dalam urin dapat memberikan gambaran adanya kelainan ginjal karena mukoprotein yang disintesa oleh tubulus ginjal membentuk silinder.

Tabel 1 Presentase hasil pemeriksaan eritrosit dalam sedimen urine per LPB

\begin{tabular}{ccc}
\hline Hasil Sel Eritrosit / LPB & Jumlah Sampel & $\mathbf{\%}$ \\
\hline$<3$ & 6 & 24 \\
$>3$ & 19 & 76 \\
\hline Jumlah & 25 & 100 \\
\hline
\end{tabular}

Keterangan : Normal 0-3 / LPB 
Tabel 2 Presentase pemeriksaan silinder dalam sedimen urin per LPB

\begin{tabular}{ccc}
\hline Hasil Silinder / LPB & Jumlah Sampel & $\mathbf{\%}$ \\
\hline- & 19 & 76 \\
$<1$ & 4 & 16 \\
$>1$ & 2 & 8 \\
\hline Jumlah & 25 & 100 \\
\hline & Normal $: 0-1 /$ LPB
\end{tabular}

\section{Simpulan dan Saran}

\section{Simpulan}

Ditemukannya jumlah eritrosit abnormal pada 19 orang (76\%) menunjukkan adanya hematuria atau kemungkinan adanya infeksi pada saluran urin, sedangkan yang menunjukkan tidak adanya hematuria atau normal sebanyak 6 orang $(24 \%)$.

Juga ditemukan silinder dalam urin pada 6 orang yaitu sebanyak $<1 /$ Lpb 4 orang $(16 \%)$ dan $>1 /$ Lpb 2 orang (8\%), ini dapat memberikan gambaran adanya kelainan ginjal atau abnormal. Dan dari hasil presentase pemeriksaan silinder dalam urin menunjukkan sebanyak 19 orang $(76 \%)$ tidak ditemukan silinder dalam urin atau normal.

\section{Saran}

Untuk penelitian selanjutnya diharapkan dapat melanjutkan penelitian bagaimana gambaran kadar ureum atau kreatinin dalam darah pada orang lanjut usia yang mengalami hipertensi.

\section{Daftar Pustaka}

Bambang, Hartono. (2011). Hipertensi the silent killer, Perhimpunan Hipertensi Indonesia.

Bell, K, Twiggs, J. and Olin, R.B. (2015). Hypertension : The Silent Killer : Updated JNC 8 Guideline Recommendations. Alabama Pharmacy association, 2.

Cameron, A.C., and Miller, D.L. (2015). "A Practitioner's guide to cluster-robust inference. "Journal of human resources, 50(2), 317-372.

Fatmah, (2010). Gizi Usia Lanjut. Jakarta, Erlangga

Gandasoebrata. (2013). Penuntun Laboratorium Klinis. Edisi 15. Dian Rakyat. Jakarta.

Hardiyanti, F. (2017). "Hubungan antara dukungan keluarga dalam penatalaksanaan hipertensi dengan tekanan darah pada lansia hipertensi di wilayah kerja Puskesmas Purwokerto selatan. "(Doctoral dissertation, Universitas Muhammadiyah Purwokerto).

Kaplan's Clinical Hypertension. (2010). 10 $0^{\text {th }}$ edition. Lippincott Williams and Wilkins. 